\title{
FLEKSIBILITAS PANEL DINDING BERDASARKAN ARAH SUMBER BUNYI PADA RANCANGAN RUANG AUDITORIUM KESENIAN JAWA TIMUR
}

\author{
Galuh Fajarwati $^{\left.1^{*}\right)}$, Asri Dinapradipta ${ }^{2)}$ \\ *) Corresponding author email : galuh.fajarwati@ar.itera.ac.id \\ 1)Program Studi Arsitektur, Institut Teknologi Sumatera, Indonesia \\ 2) Department Arsitektur, Institut Teknologi Sepuluh Nopember, Indonesia
}

\author{
Article info \\ MODUL vol 21 no 2, issues period 2021 \\ Doi : : 10.14710/mdl.21.2.2021.162-170 \\ Received : 17 Agustus 2021 \\ Revised : 23 Desember 2021 \\ Accepted : 30 Desember 2021
}

\begin{abstract}
Abstrak
Pengembangan kesenian daerah melalui perencanaan dan perancangan Auditorium Kesenian Jawa Timur merupakan program yang diinisiasi oleh pemerintah daerah. Isu krusial dalam perancangan auditorium ialah kenyamanan akustik. Untuk memfasilitasi kenyamanan penyebaran akustik, perancangan fleksibilitas panel dalam auditorium perlu dipertimbangkan untuk merespon keberagaman pementasan seperti teatrikal, musik, dan pementasan sendatari. Penelitian ini bertujuan untuk mengidentifikasi konsep pola pergerakan fleksibilitas elemen dinding interior ruang auditorium dalam memenuhi kebutuhan akustik ruang pada rancangan Auditorium Kesenian Jawa Timur. Penelitian ini merupakan tahap awal dari rangkaian pengujian efektivitas pergerakan panel dinding interior ruang auditorium. Penelitian ini menghasilkan konsep dari simulasi manual teori dasar pemantulan akustik. Peneliti melakukan observasi lapangan untuk mengidentifikasi sumber suara utama pada saat pementasan. Peneliti kemudian menguji konsep pergerakan dinding, material, dan penentuan arah hadap panel berdasarkan teori dasar pemantulan bunyi terhadap bidang datar. Kemungkinan faktor cacat akustik yang terjadi juga menjadi pertimbangan respon suara yang dihasilkan. Dari hasil analisis pemantulan bunyi, dapat disimpulkan bahwa panel dinding pada auditorium setidaknya dapat beradaptasi menjadi empat konfigurasi konsep ruang dengan tiga adaptasi dinding yaitu: panel dinding lurus dengan material peredam;
\end{abstract}

Fajarwati, Dinapradipta panel dinding lurus dengan material pemantul; panel dinding miring dengan panel pemantul.

Kata kunci: Akustik; Auditorium; Fleksibilitas; Panel dinding

\section{PENDAHULUAN}

Peningkatan apresiasi seni dan kreativitas karya budaya dalam rancangan awal RPJMN 2015-2019 memaparkan bahwa keragaman seni, karya budaya dan tradisi merupakan kekayaan budaya bangsa yang perlu dipelihara, dilindungi dan dikembangkan oleh masyarakat. Peningkatan apresiasi seni pada provinsi Jawa Timur melakukan penyediaan wadah kesenian ini difokuskan pembangunannya di Kota Surabaya yang juga merupakan respon dari adanya rencana pengembangan kawasan Balai Pemuda sebagai kawasan cagar seni dan budaya Kota Surabaya.

Keterikatan pembangunan dengan beragam jenis kegiatan yang harus ditampung dan ketersediaan lahan yang cukup minim merupakan salah satu masalah yang harus dipecahkan. Kesenian di Jawa Timur memiliki struktur pementasan dan arah sumber suara yang sangat beragam. Perbedaan struktur pementasan dan masalah akustik ini akan sangat berpengaruh pada akustik ruang dan kenyamanan penonton dalam bidang akustik. Sehingga agar auditorium kesenian dapat mewadahi semua jenis aktivtas dengan kenyamanan akustik perlu adanya adaptasi elemen akustik di dalam ruang auditorium.

Maka ruang auditorium ini memiliki kepentingan untuk menerapkan konsep fleksibilitas pada panel dinding ruang auditorium. Adaptasi elemen panel dinding di pilih sebagai fokus penelitian ini dikarenakan dinding merupakan elemen pembentuk ruang yang memiliki bidang paling besar dan memiliki pengaruh yang cukup besar sebagai elemen akustik

Tujuan dalam penelitian ini yaitu untuk menemukan kofigurasi panel dinding yang efektif dalam merespon 
penyebaran akustik di setiap jenis pementasan kesenian Jawa Timur. Dengan hasil yang diharapkan akan berupa konsep-konsep konfigurasi pergerakan arah panel dinding sebagai bentuk felksibilitas ruang auditorium untuk memenuhi kebutuhan dan kenyamanan akustik dalam setiap arah asal sumber suara yang berbeda.

\section{STUDI LITERATUR}

\section{Jenis kesenian Jawa Timur dan Sumber Suara}

Jenis kesenian Jawa Timur yang dipilih dan dianalisis merupakan jenis kesenian tari dan lakon. Jenis kesenian tersebut merupakan jenis kesenian yang sangat membutuhkan kenyamanan akustik pada saat pementasan. Jenis kesenian tari dan lakon biasanya akan diiringi dengan musik tradisional pada saat pementasan sehingga pengaturan akustik sangat diperlukan. Jenis kesenian tari pada kesenian Jawa Timur memiliki beberapa cara dalam pementasanya. Beberapa jenis kesenian tari yang dipilih merepresentasikan jenis kesenian tari yang memiliki cara pementasan yang sama dan sumber suara yang sama. Misal tari lahbako dengan tari Tari Mual Sangkal sumber suara berasal dari rekaman atau speaker sehingga salah satu tari tersebut dipilih menjadi perwakilan. Jenis tari tersebut kemudian dikelompokkan berdasarkan sumber suara. Peneliti kemudian membuat visualisasi sumber suara pada layout ruang auditorium Jawa Timur (lihat Tabel 1dan 2).

Tabel 1. Pengelompokkan sumber suara berdasarkan pementasan tari.

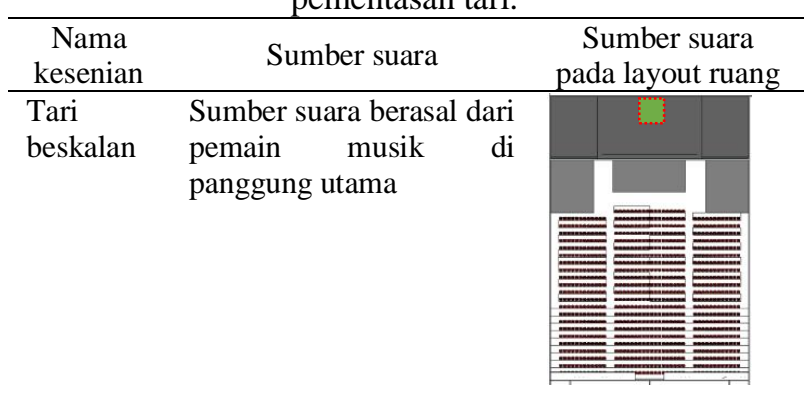

\begin{tabular}{lll}
\hline Giri gora & \multicolumn{2}{l}{ Sumber suara berasal dari } \\
dahuru & pemain & musik di \\
daha & panggung & musik kanan \\
& ruangan. & \\
&
\end{tabular}

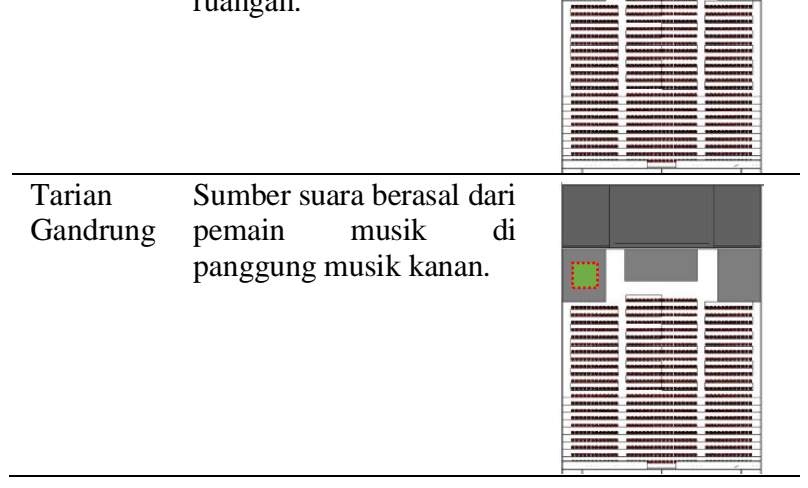

\begin{tabular}{lll}
\hline $\begin{array}{c}\text { Nama } \\
\text { kesenian }\end{array}$ & \multicolumn{1}{c}{ Sumber suara } & $\begin{array}{c}\text { Sumber suara } \\
\text { pada layout ruang }\end{array}$ \\
\hline Lahbako & $\begin{array}{l}\text { Sumber suara berasal dari } \\
\text { pengeras suara yang di } \\
\text { pasang menyebar di } \\
\text { ruangan }\end{array}$ \\
\hline Remo & $\begin{array}{l}\text { Sumber suara berasal dari } \\
\text { pemain musik pada } \\
\text { panggung musik kanan } \\
\text { dan penari di panggung } \\
\text { utama. }\end{array}$ \\
\hline
\end{tabular}

Selain kesenian tari, peneliti akan mengidentifikasi jenis kesenian lakon. Kesenian lakin merupakan perpaduan dari 2 kesenian yaitu drama dan musik sebagai pengiring pementasan. Sumber suara pada pementasan lakon berasal dari 2 arah sumber yang berbeda yaitu pada panggung utama dan panggung musik yang biasanya terdiri dari 3 lokasi yang dapat dipilih salah satunya seperti panggung musik kanan, panggung musik kiri, atau panggung musing tengah. Jenis kesenian lakon yang akan dianalisis merupakan perwakilan dari jenis kesenian lakon yang memiliki struktur pementasan yang sama. Jenis kesenian lakon tersebut adalah:

Tabel 2. Pengelompokkan sumber suara berdasarkan pementasan lakon.

\begin{tabular}{ccc}
\hline $\begin{array}{c}\text { Nama } \\
\text { kesenian }\end{array}$ & Sumber suara & $\begin{array}{c}\text { Sumber suara } \\
\text { pada layout ruang }\end{array}$ \\
\hline Kethoprak & $\begin{array}{l}\text { Sumber suara berasal } \\
\text { dari pemain musik di } \\
\text { pangung musik kiri dan } \\
\text { berasal dari pelakon di } \\
\text { panggung utama }\end{array}$
\end{tabular}

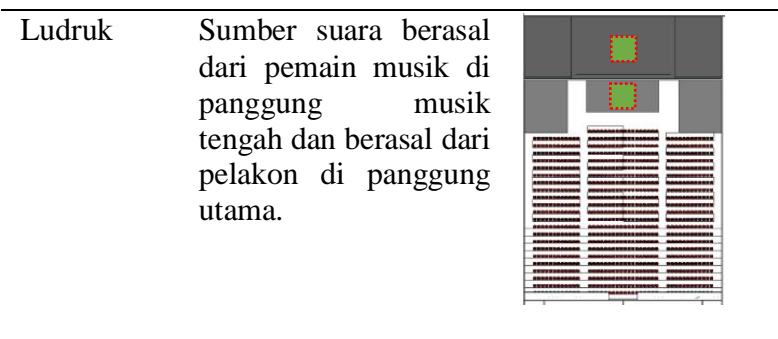




\begin{tabular}{lll}
\hline $\begin{array}{c}\text { Nama } \\
\text { kesenian }\end{array}$ & \multicolumn{1}{c}{ Sumber suara } & $\begin{array}{c}\text { Sumber suara } \\
\text { pada layout ruang }\end{array}$ \\
\hline $\begin{array}{l}\text { Wayang } \\
\text { Timplong }\end{array}$ & $\begin{array}{l}\text { Sumber suara berasal } \\
\text { dari pemain musik dan } \\
\text { dalang dari panggung } \\
\text { musik tengah. }\end{array}$ & \\
\hline
\end{tabular}

Wayang
Topeng $\begin{aligned} & \text { Sumber suara berasal } \\ & \text { dari pemain musik dan } \\ & \text { dalang yang berada di } \\ & \text { panggung musik } \\ & \text { kanan. }\end{aligned}$

\section{Fleksibilitas elemen akustik pada ruang kesenian}

Fleksibilitas dilakukan untuk merespon situasi yang berubah dalam penggunaan, pengoperasian, atau lokasi. fleksibilitas adalah arsitektur yang mengadaptasi, berkelanjutan, berinteraksi dengan pengguna daripada menghambat, dan sebagai reson terhadap masalah kontemporer yang terkait dengan perubahan teknologi, sosial, dan ekonomi, (Kronenburg, 2007). Sementara itu, menurut Groak (1992), desain yang fleksibel mampu melakukan pengaturan fisik yang berbeda.

Fleksibilitas memiliki kategori khusus jenis fleksibilitas bangunan (Thomas, 2013 dan Kronenburg, 2007) telah diidentifikasi sebagai berikut: Adaptable, Movable, Responsive, Transformable. Adaptable, mengacu pada dimana modifikasi dalam bangunan yang ada dimungkinkan (Thomas, 2013). Movable, merupakan struktur yang mampu disintegrasi, diposisikan ulang, dan dipasang kembali ke lokasi lain (Thomas, 2013). Responsive, dimana bangunan dapat merespons dan berinteraksi dengan berbagai dinamika eksternal seperti kondisi lingkungan - respons terhadap iklim dan faktorfaktor lain seperti tingkat hunian dan penggunaan. (Thomas, 2013 dan Kronenburg, 2007). Sedangkan Transformable, dicirikan oleh desain modular, yang mampu menambah dan melepaskan komponen serta untuk membuka dan menutup sehingga berubah bentuk. Jenis ruang semacam itu memungkinkan pertumbuhan teratur dengan penggunaan sistem struktural yang efisien. (Thomas 2013 dan Kronenburg, 2007).

Doelle (1985) menyatakan bahwa tingkat kekerasan bunyi terjadi karena energi yang hilang pada perambatan gelombang bunyi dan penyerapan yang besar oleh penonton dan isi ruang (tempat duduk empuk, karpet, tirai dan lain-lain). Hilangnya energi bunyi dapat dikurangi dan kekerasan suara yang cukup dapat diadakan dengan cara-cara sebagai berikut:

1. Auditorium harus dibentuk agar penonton sedekat mungkin dengan sumber bunyi, dengan demikian mengurangi jarak yang harus ditempuh bunyi.

2. Sumber bunyi harus dinaikkan agar sebanyak mungkin terlihat, sehingga menjamin aliran gelombang bunyi langsung yang bebas (gelombang yang merambat secara langsung dari sumher bunyi tanpa pemantulan) ke tiap pendengar.

3. Sumber bunyi harus dikelilingi oleh permukaanpermukaan pemantul bunyi (plaster, gypsum board, plywood, plexiglas, papan plastik kaku, dan lain-lain) yang besar dan banyak; untuk memberikan energi bunyi pantul tambahan pada tiap bagian dari area penonton, terutama pada tempat-tempat duduk yang jauh. Langit-langit dan dinding samping auditorium selalu merupakan permukaan yang cocok untuk digunakan sebagai pemantul bunyi.

4. Permukaan pemantul bunyi yang paralel (horizontal maupun vertikal), terutama yang dekat dengan sumber bunyi, harus dihindari, untuk menghilangkan pemantulan kembali yang tidak diinginkan ke sumber bunyi.

5. Penonton harus berada di daerah penonton yang menguntungkan, baik dalam hal melihat maupun mendengar. Daerah tempat duduk yang sangat lebar harus dihindari.

6. Bila di samping sumber bunyi utama yang biasanya ditempatkan di bagian depan auditorium, terdapat sumber bunyi tambahan di bagian lain ruang maka sumber bunyi tambahan ini harus dikelilingi juga oleh permukaan pemantul bunyi. Dalam tiap auditorium, sebanyak mungkin energi bunyi harus dipancarkan dari semuaposisi "pengirim" ke semua daerah "penerima".

7. Di samping permukaan pemantul yang berfungsi menguatkan bunyi langsung ke penonton, permukaan pemantul tambahan harus disediakan untuk mengarahkan bunyi kembali ke pementas. Hal ini penting terutama dalam auditorium yang dirancang untuk pertunjukan musik atau vokal

\section{Akustik}

Barron, (1993) menjelaskan bahwa teori dasar pergerakan suara yaitu geometri refleksi. Seperti pada Gambar 1, suara yang dipantulkan berperilaku seolaholah itu berasal dari titik sumber ke dinding dan terjadi pemantulan dimana kejadian atau suara yang dipantulkan adalah sama. 


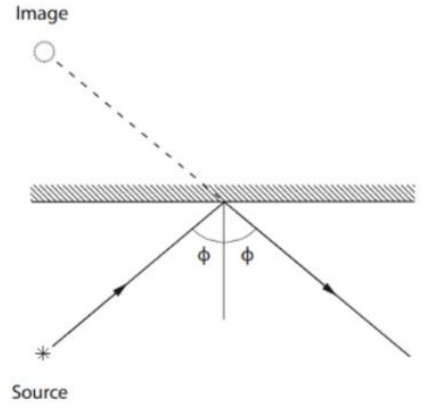

Gambar 1. Sudut, $\varphi$, suara datang dan suara yang dipantulkan adalah sama. (Sumber: Theatre Building a Design Guide, Judith Strong (2010))

Pemantulan suara pada sebuah ruang yaitu kesegala arah dan akan memantul sesuai dengan hukum akustik yaitu Sudut, $\varphi$, suara datang dan suara yang dipantulkan adalah sama (Strong, 2010). Pergeran pantulan dalam ruang tergambarkan pada gambar $\mathrm{x}$.

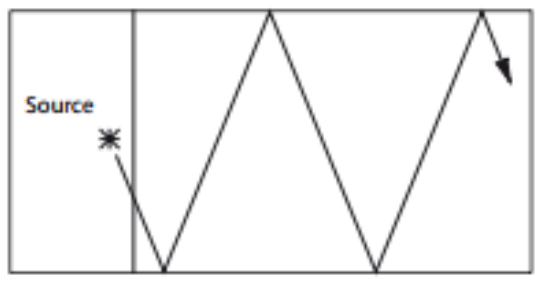

Gambar 2. Persebaran suara di dalam ruang (Sumber: Barron, 2010)

Kinerja akustik ruang auditorium menyatakan kemampuan auditorium tersebut untuk menjalankan fungsinya, yaitu bagaimana pendengar dapat menangkap dan memahami dengan baik dan utuh suara yang telah dipancarkan oleh pembicara atau pemusik (Indrani, 2007). Dari Gambar 2, dijelaskan bahwa pantulan suara pada ruangan dapat menyebar dengan merata jika dipantulkan namun pada pemantulan di area tertentu akan menghasilkan gema pada ruangan. Hal ini sangat dihindari pada ruangan auditorium. Gema tentu bisa jelas dan merusak (Barron, 2010).

\section{METODE PENELITIAN}

Penelitian ini bersifat kualitatif. Peneliti melakukan beberapa tahap untuk mengidentifikasi konsep pola pergerakan fleksibilitas elemen dinding interior ruang auditorium. Pada tahap awal, peneliti melakukan pengumpulan jenis pementasan kesenian Jawa Timur dari literatur. Kesenian yang dipilih yaitu representasikan kesenian yang memiliki sumber bunyi yang sama pada saat pementasan. Adapun, kesenian tersebeut dapat dilihat pada Tabel: 1 dan 2. Pada tahap kedua dilakukan pendataan sumber bunyi di setiap perwakilan kesenian tradisional Jawa Timur yang telah terpilih melalui observasi lapangan. Sumber bunyi dinyatakan dalam kotak hijau dengan garis merah putus-putus (Tabel 1 dan 2).

Pada tahap selanjutnya dilakukan perancangan ruang auditorium dengan luasan yang disesuaikan pada standar ruang pementasan. Setelah ruang auditorium dirancang, dilakukan pengkondisian letak sumber bunyi sesuai dengan arah sumber bunyi di setiap jenis pementasan yang dipilih berdasarkan hasil observasi. Kemudian penyebaran bunyi pada ruang dan analisis dilakukan dengan dasar teori pemantulan bunyi di dalam ruang oleh Barron (2010) dan Strong (2010). Bunyi yang dipantulkan ke dinding pantul akan mengakibatkan pantulan dengan sudut pantul yang sama dengan sudut datang bunyi asli. Suara yang keluar dari sumber bunyi diasumsuikan menyebar merata ke semua ruangan sehingga untuk meminimalisir terjadinya cacat akustik seperti gema dan gaung yang diakibatkan pantulan bunyi berulang atau pantulan bunyi yang Kembali ke sumber. Sehingga pada tahap selanjutnya dilakukan analisis pengolahan pergerakan panel dinding yang dapat mengurangi dampak negatif pada bunyi di dalam ruang auditorium berdasarkan setiap jenis arah sumber suara. Pada tahap ini dilakukan secara manual dengan menerapkan teori dasar penyebaran bunyi yaitu bunyi datang akan dipantulkan dengan sudut yang sama besar dengan bunyi utama.

Di akhir penelitian akan didapatkan konsep kemungkinan berupa konfigurasi ruang yang dipengaruhi oleh panel dinding berdasarkan arah sumber bunyi yang berbeda.

\section{HASIL PENULISAN, ANALISIS, DAN DISKUSI Pengelompokkan Kesenian Tradisional Jawa Timur dan Penyebaran Suara pada dinding}

Kesenian Jawa Timur yang akan dianalisis merupakan kesenian pementasan yang terdiri dari beberapa jenis yaitu teater, tari, dan musik sebagai bagian dari pementasan. Kesenian yang dipilih merupakan jenis kesenian yang mewakili kesenian yang memiliki kesamaan arah sumber bunyi pada saat pementasan. Dalam fleksibilitas pergerakan panel dinding interior auditorium setidaknya dapat memenuhi kebutuhan penyebaran akustik yang baik untuk kenyamanan penonton dan mengurangi cacat akustik. Dalam menyelesaikan masalah penyebaran akustik dan kecacatan akustik, pergerakan panel dinding akan menyesuaikan pada strategi auditorium yang dipaparkan oleh Doelle (1985).

Dari arah sumber suara dari pengelompokan jenis kesenian dan sumber suaranya, dapat disimpulkan bahwa terdapat 8 arah sumber suara yang harus direspon oleh ruang auditorium (tabel 3). Persebaran suara di dalam ruang merata ke seluruh ruang sehingga diperlukan respon panel dinding agar meminimalisir cacat akustik 
ruang. Pada Tabel 3, merupakan konfigurasi sumber suara yang dapat terjadi di dalam ruang auditorium dan respon ruang. Pada tabel 3, Garis merah merupakan ilustrasi bagaimana suara dipantulkan.

Auditorium membutuhkan serangkaian refleksi awal dari dinding samping agar suara sampai ke penonton secara merata. Dengan demikian, penggunakan dinding samping ruang akan memanfaatkan material dengan fungsi memantulkan dan mengarahkan suara. Namun, pada sisi depan (saat dibutuhkan) dan belakang ruang aula akan memanfaatkan material dengan fungsi peredam sehingga meminimalisir pemantulan suara yang mengakibatkan gema pada ruangan.

Pergerakan element dinding ruang akan mempertimbangkan teori dasar pergerakan suara menyesuaikan pada geometri refleksi oleh Barron, (1993). Dalam menyelesaikan masalah penyebaran suara dan kecacatan akustik dalam aula utama akan menyesuaikan pada strategi auditorium yang dipaparkan oleh doelle (1985) sehingga alternatif konfigurasi panel dinding yang dapat terjadi pada aula utama agar pesebaran suara merata terdengan ke penonton seperti pada tabel 3.

Tabel 3. Analisis kesenian sendatari tradisional Jawa Timur

\begin{tabular}{c|c|c}
\hline $\begin{array}{c}\text { Konfigurasi } \\
\text { berdasarkan arah } \\
\text { sumber suara }\end{array}$ & $\begin{array}{c}\text { Sumber suara } \\
\text { pada Senitari }\end{array}$ & $\begin{array}{c}\text { Respon dari } \\
\text { Penyebaran } \\
\text { suara }\end{array}$ \\
\hline \multirow{1}{*}{ Tipe A } & & \\
Tipe B & & \\
\hline \multirow{1}{*}{ Tipe C } & & \\
\hline
\end{tabular}

\begin{tabular}{|c|c|c|}
\hline $\begin{array}{c}\text { Konfigurasi } \\
\text { berdasarkan arah } \\
\text { sumber suara }\end{array}$ & $\begin{array}{l}\text { Sumber suara } \\
\text { pada Senitari }\end{array}$ & $\begin{array}{c}\text { Respon dari } \\
\text { Penyebaran } \\
\text { suara }\end{array}$ \\
\hline Tipe E & 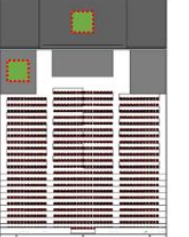 & $\frac{6}{1}$ \\
\hline Tipe F & 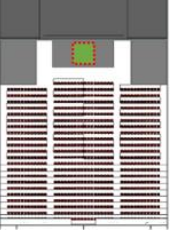 & 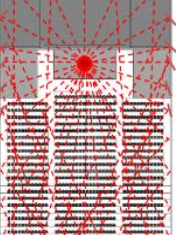 \\
\hline Tipe G & 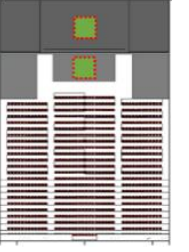 & ${ }^{30}=$ \\
\hline Tipe H & 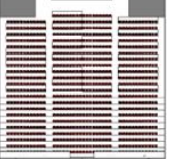 & 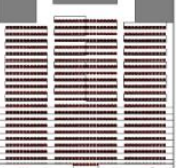 \\
\hline
\end{tabular}

\section{Konfigurasi elemen panel dinding}

Dalam setiap konfigurasi yang terjadi di dalam auditorium dalam tabel 3 mempertimbangkan efek-efek negatif yang mungkin akan terjadi dan mengganggu akustik ruang. Penggunaan material pada panel dinding menjadi fokus utama dalam menangani kasus akustik di dalam ruang auditorium. Pengolahan penggunaan material panel dinding dikarenakan kualitas suara dalam suatu ruang pada hakikatnya tergantung pada sifat-sifat penutup ruang, Ching (2009). Dalam Long (2006), akustik ruang arsitektur sebagai ilmu maupun sebagai seni dan tidak luput dari aspek penanganan kebisingan, getaran dan juga pengembangan bahan bangunan yang efektif.

Pada ruang auditorium, proyeksi suara akan disesuaikan dengan sudut datang dan arah penyebaran yang diinginkan. Sehingga pengaturan material panel dinding yang tepat menjadi salah satu sumber kesuksesan penyebaran akustik. Panel dinding akan memiliki 2 sisi dengan material yang berbeda yaitu pemantul dan penyerap seperti digambarkan pada gambar 3. Sehingga dapat digunakan sesuai dengan kebutuhan setiap arah sumber suara yang berbeda.

Konfigurasi dinding auditorium seni akan diatur kemiringannya yang dapat mengarahkan bunyi sehingga dapat mendukung kekerasan audio dan meminimalisir 
gema. Dinding belakang auditorium didesain agar dapat menyerap bunyi sehingga dapat menghindari cacat akustik seperti gema dan difusi. Dari hasil analisis respon dari penyebaran suara dalam ruang auditorium di simpulkan terdapat 4 konsep konfigurasi respon panel dinding yang dapat digunakan untuk mengurangi dampak cacat akustik di dalam ruang auditorium. Hal ini dikarenakan adanya kesamaan respon yang terjadi di beberapa tipe arah sumber suara. Beberapa arah sumber suara yang memiliki kesamaan respon panel dinding tersebut yaitu:

1. konfigurasi I (Tipe A, F, dan $\mathrm{H}$ )

2. konfigurasi II (Tipe $\mathrm{B}$ dam D)

3. konfigurasi III (Tipe $\mathrm{C}$ dan $\mathrm{G}$ )

4. konfigurasi IV (Tipe $\mathrm{H}$ )

Terdapat beberapa respon panel dinding di dalam ruang auditorium yaitu; A (Panel dinding rata dengan material peredam); B (Panel dinding rata dengan panel pemantul); C (Panel dinding miring dengan material pemantul). Secara lengkap respon panel dinding A, B, C secara lengkap dijelaskan sebagai berikut:

a. Panel dinding rata dengan material peredam

Dinding memiliki 2 material yang digunakan dan dapat diputar seperti pada gambar 3. Pada konfigurasi ini, panel dinding rata lurus dengan menggunakan material peredam dibutuhkan untuk kebutuhan meredam suara yang datang ke bidang panel dinding. Material peredam yang akan digunakan yaitu material dengan jenis karpet yang mampu meredam suara. Penggunaan karpet akan memfokuskan pada warna warna gelap sehingga tidak mencolok dan memecahkan fokus perhatian.

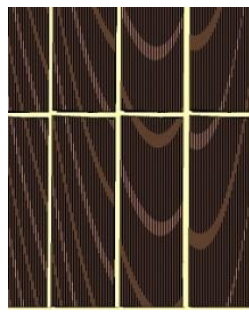

(a)

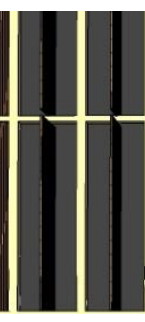

(b)

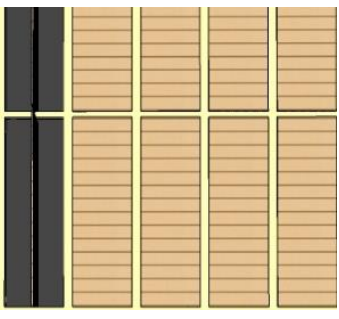

(c)
Gambar 3. Penerapan material dan arah panel dinding pada auditorium sesuai sumber bunyi tipe A (a: material pemantul; b: panel diputar; c: material penyerap).
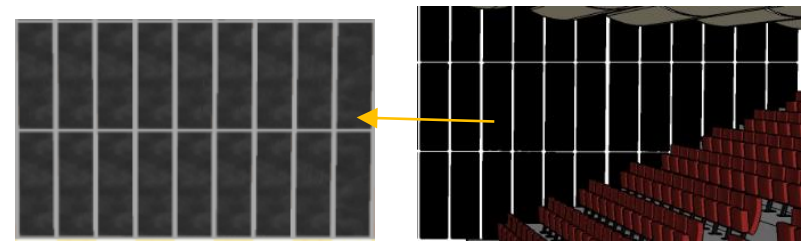

Gambar 4. Penerapan material dan arah panel dinding pada auditorium sesuai sumber bunyi tipe $A$.

\section{b. Panel dinding rata dengan panel pemantul}

Panel dinding berada pada sisi yang menggunakan material pemantul. Dimana material yang digunakan material yang dapat memantulkan akustik dengan baik. Pada bagian ini, dinding diatur lurus pada dinding untuk memenuhi kebutuhan arah pantul suara yang diharapkan. Material panel dinding yang digunakan yaitu material GRG (glass-fiber reinforced gypsum) acoustic wall panel.

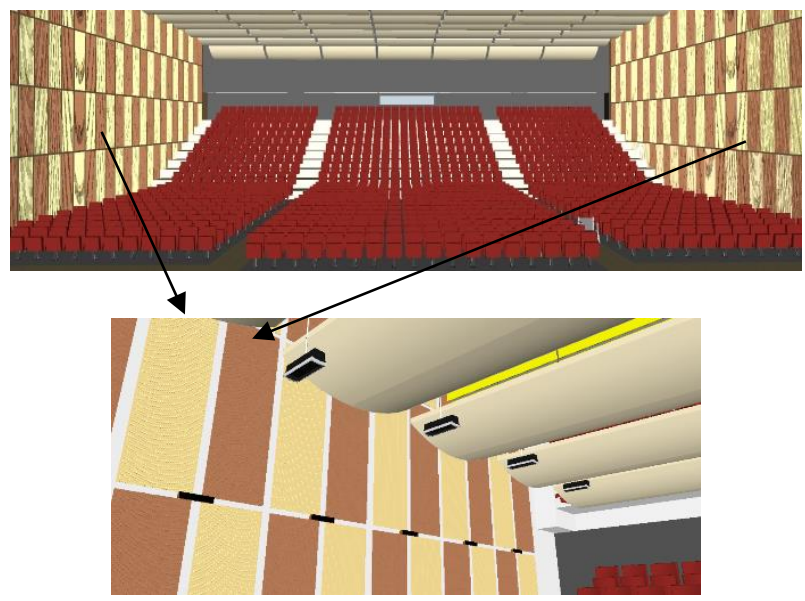

Gambar 5. Penerapan material dan arah panel dinding pada auditorium sesuai sumber bunyi tipe B.

c. Panel dinding miring dengan material pemantul

Konfigurasi panel dinding dimiringkan dari kemiringan dengan sudut kemiringan yang kecil ke sudut kemiringan yang tinggi $\left(<90^{\circ}\right)$. Kemiringan panel dinding diperlukan sebagai upaya untuk mengarahkan pantulan suara ke arah yang diharapkan sehingga penyebaran suara dapat merata. Konsep kemiringan pada panel dinding ini yaitu berurut dari sudut kemiringan yang rendah hingga tinggi seperti tergambarkan pada gambar 6 . Banyaknya panel yang dimiringkan akan disesuaikan pada area- area yang membutuhkan respon tersebut.

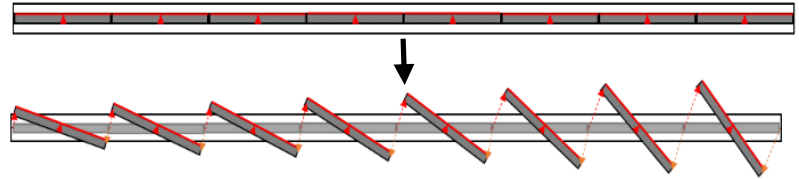

Gambar 6. Kemiringan yang terjadi pada panel dalam beradaptasi.

Penjelasan secara detail perubahan elemen dinding ruang dalam 4 konfigurasi respon dalam aula utama dipaparkan seperti berikut: 
a. Panggung dengan penel dinding konfigurasi I

Panggung dengan konfigurasi panel dinding tipe I merupakan strategi agar akustik dapat dipantulkan merata keseluruh ruangan dan mengurangi cacat akustik maka penjelasan penerapan panel dan material panel dinding lebih detail seperti pada gambar $\mathrm{xx}$.

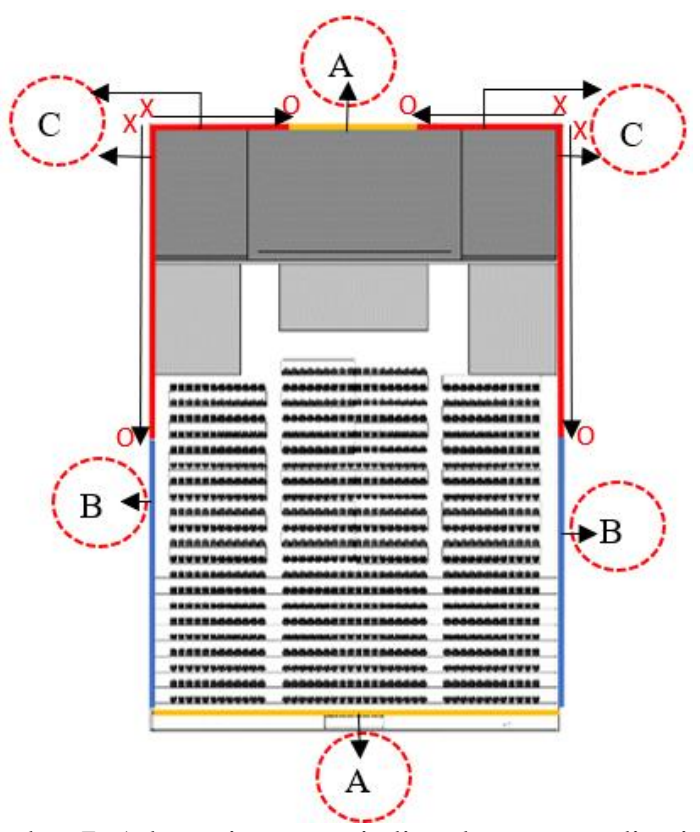

Gambar 7. Adaptasi yang terjadi pada ruang auditorium sebagai konfigurasi I.

Konfigurasi panel dinding tipe I merupakan respon dari sumber suara Tipe A, F, dan $\mathrm{H}$ seperti yang dijelaskan pada tabel xx. Respon terjadi pada 4 bidang dinding yaitu; pada dinding depan penonton (dekat panggung) terjadi 2 respon pada panel yaitu panel lurus dengan material penyerap di sisi tengah dinding dan di kanan serta kirinya merupakan panel pemantul yang di miringkan. Pada dinding kanan dan kiri auditorium respon berupa penerapan dinding pemantul yang dimiringkan pada area dekat panggung dan panel dinding lurus pada area penonton. Sedangkan pada dinding belakang ruang auditorium, respon berupa penerapan panel dinding lurus dengan material penyerap. Kemiringan yang terjadi pada dinding terjadi seperti pada gambar 6.

\section{b. Panggung dengan panel dinding konfigurasi II}

Panggung dengan konfigurasi panel dinding II merupakan respon untuk kebutuhan sumber suara dengan tipe B dan D (terjelaskan pada tabel 3). Detail terjadinya respon seperti pada gambar berikut:

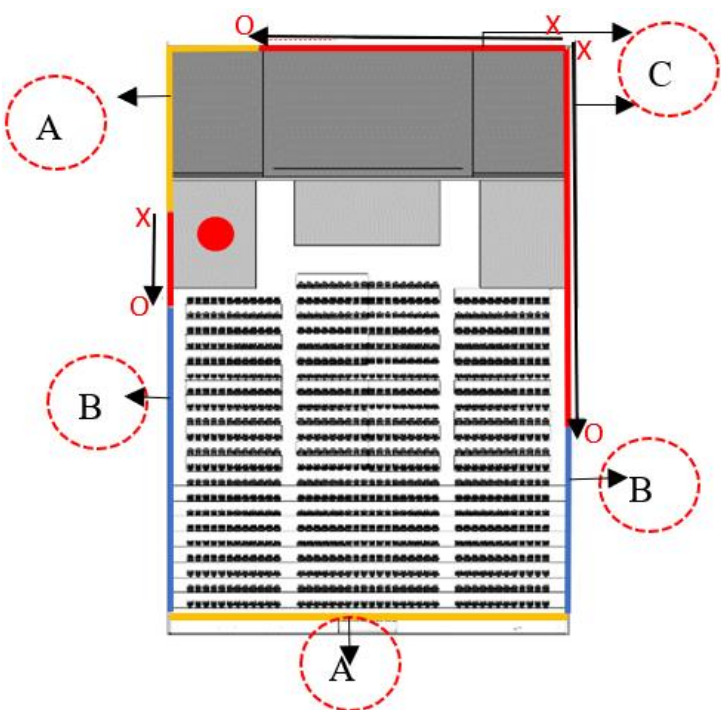

Gambar 8. Adaptasi panel dinding yang terjadi pada ruang auditorium sebagai konfigurasi II.

Respon yang terjadi pada konfigurasi tipe II ini yaitu terjadi 4 bidang dinding ruang. Pada dinding depan (belakang panggung) akan merespon dengan penerapan dinding peredam pada sisi kiri bidang dinding sedangkan hamper $3 / 4$ bidang dinding sisanya akan diberlakukan respon dengan penerapan dinding miring dan material pemantul. Pada dinding kanan ruang akan memiliki 2 respon yang berbeda yaitu pada bidang dinding yang dekat dengan panggung akan menerapkan panel dinding dengan kemiringan dan material panel berupa panel pemantul. Sedangkan pada dinding kiri pada auditorium akan merespon dengan 3 konfigurasi panel yaitu pada area dinding yang dekat dengan panggung utama akan menggunakan material peredam dengan dinding lurus, pada area yang dekat dengan panggung musik akan menggunakan material pemantul dengan kemiringan yang diatur. Pada sisi yang dekat dengan penonton akan menerapkan material penyerap dengan dinding lurus. Kemudian pada bidang dinding belakang ruang akan menggunakan material dinding berupa peredam dengan panel dalam keadaan lurus.

c. Panggung dengan penel dinding konfigurasi III

Dari sumber bunyi tipe III agar suara dapat dipantulkan merata keseluruh ruangan dan meminimalisir cacat akustik yang dihasilkan maka panel dinding memiliki respon pada ruang auditorium seperti pada gambar 9 berikut ini: 


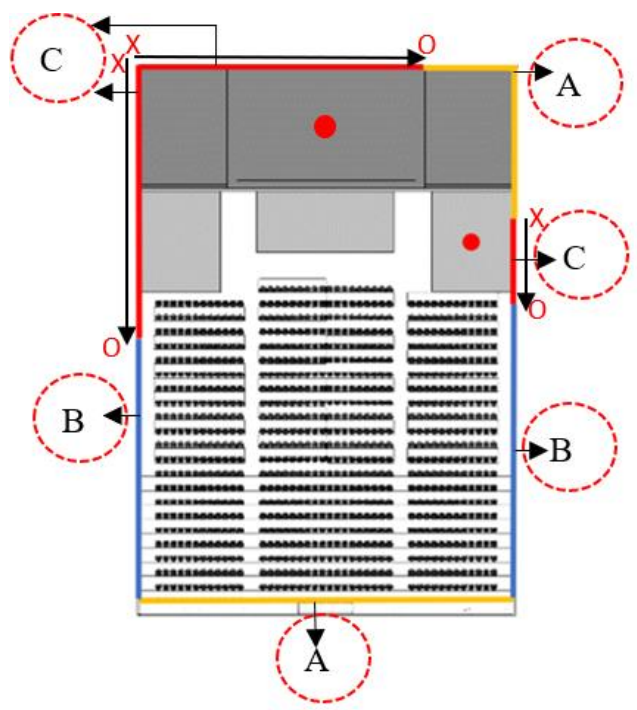

Gambar 9. Adaptasi penel dinding yang terjadi pada ruang auditorium sebagai konfigurasi III.

Konfigurasi yang terjadi merupakan respon dari sumber suara dengan tipe $\mathrm{C}$ dan $\mathrm{G}$. respon yang terjadi pada konfigurasi ini yaitu terjadi pada seluruh dinding ruang. Pada area depan ruangan (belakang panggung) terjadi respon dengan penerapan dinding peredam pada sisi kanan bidang dinding sedangkan hampir 3/4 bidang dinding sisi kiri akan diberlakukan respon dengan penerapan dinding miring dan material pemantul. Pada dinding kiri ruang akan memiliki 2 respon yang berbeda yaitu pada bidang dinding yang dekat dengan panggung akan menerapkan panel dinding dengan kemiringan dan material panel berupa panel pemantul. Sedangkan pada dinding kanan pada auditorium akan merespon dengan 3 konfigurasi panel yaitu pada area dinding yang dekat dengan panggung utama akan menggunakan material peredam dengan dinding lurus, pada area yang dekat dengan panggung musik akan menggunakan material pemantul dengan kemiringan yang diatur. Pada sisi yang dekat dengan penonton akan menerapkan material penyerap dengan dinding lurus. Sedangkan pada sisi dinding belakang panggung akan menerapkan material peredam dengan dinding lurus.

\section{d. Panggung dengan konfigurasi panel dinding (iii)}

Panggung dengan kebutuhan respon panel dinding dengan konfigurasi IV dijelaskan lebih detail seperti pada gambar 10. Kebutuhan akustik pada jenis ini yaitu berasal dari pengeras suara sehingga secara umum suara dapat tersebar dengan rata keseluruh ruang dengan sangat baik. Pengolahan konfigurasi dilakukan untuk meminimalisir gema yang dihasilkan dari pantulan suara dalam ruang. Sehingga elemen panel dinding yang digunakan yaitu berada pada panel penyerap dan dengan posisi lurus seperti pada gambar 10. Sehingga suara pada ruang auditorium dapat diserap dan tidak dipantulkan kembali ke sumber suara dan menimbulkan cacat akustik.

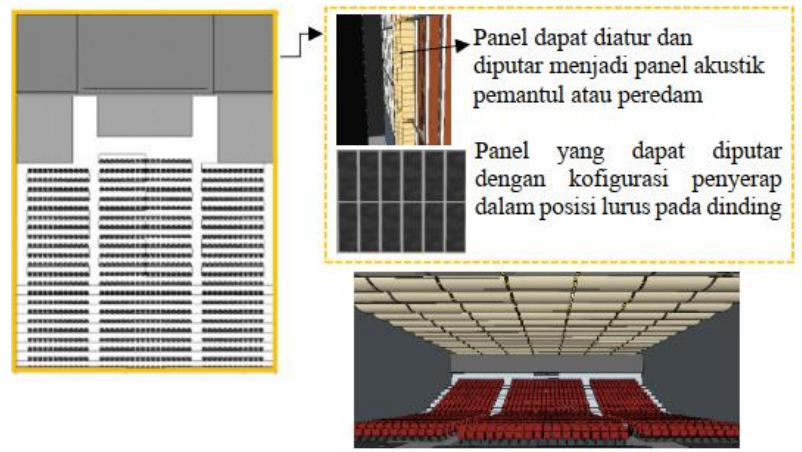

Gambar 10. Adaptasi panel dinding yang terjadi pada ruang auditorium sebagai konfigurasi IV.

Dari hasil analisis yang dilakukan terdapat 4 konfigurasi yang dapat merespon dari 8 sumber suara yang dibutuhkan oleh setiap jenis kesenian tradisional Jawa Timur. Setiap konfigurasi memiliki kebutuhan untuk meminimalisir cacat akustik dan memaksimalkan penyebaran suara merata keseluruh ruangan. Respon yang terjadi di dalam ruang merupakan respon dari penel dinding dan penggunaan material yang tepat antara penyerap atau pemantul.

\section{KESIMPULAN}

Dari hasil analisis yang dilakukan, dapat disimpulkan bahwa sebuah ruang auditorium memungkinkan untuk melakukan adaptasi panel dinding dalam ruang untuk merespon perbedaan arah sumber bunyi dari berbagai aktivitas kesenian. adaptasi yang terjadi pada ruang auditorium menghasilkan 4 konfigurasi ruang dengan 3 tipe respon panel dinding yaitu (A) panel dinding lurus dengan material peredam; (B) panel dinding lurus dengan material pemantul; (C) panel dinding miring dengan panel pemantul.

konfigurasi ruang yang dihasilkan beradaptasi dengan 8 sumber suara yang berbeda saat pementasan kesenian Jawa Timur. Namun, secara detail sudut kemiringan bisa terjadi perbedaan yang sangat signifikan, dan harus dibuktikan pada tahap penelitian lebih lanjut. Penelitian selanjutnya dibutuhkan pengujian dengan melakukan penelitian dengan simulasi akustik. Dengan demikian, dapat diketahui berapa jumlah dan sudut kemiringan panel akustik.

\section{Ucapan terimakasih}

Peneliti berterimakasih kepada prodi magister ITS dan terimakasih kepada prodi ITERA yang telah mendukung kegiatan penelitian ini. Peneliti juga berterimakasih kepada pengamat kesenian Jawa Timur yang telah memberikan banyak pemahaman tentang jenis 
kesenian dan bagaimana proses kesenian Jawa Timur berlangsung.

\section{REFERENSI}

Barron, Michael. (1993) Auditorium Acoustics and Architectural Design, Spon Press, Canada.

Ching, F.D.K, (2007), Form, Space, and Order, John Wiley and Sons, New York.

Doelle, L.L, (1972), Environtmental Acoustic, McGrawHill Publishing Company, New York

Groák, Steven. (1992) The Idea of Building: Thought

and Action In the Design and Production Of Buildings, E $\&$ FN Spon, London.

Groat, L., \& Wang, D. (2013) Architectural Research Methods (Second Edition), New Jersey: John Wiley \& Sons, Inc.
Kronenburg, Robert. (2007) Flexibility Architecture, Laurence King: London, UK.

Leitermann, Menurut. (2017) Theater Planning: Facilities for Performing Arts and Live Entertainment, Routledge, New York.

Long, M, (2006), Architectural Acoustics, Elsevier, Oxford UK.

Strong, Judith. (2010) Theatre Building a Design Guide, Routledge, Canada.

Thomas, Susan, p. (2013) Building Flexibility: The Extend to Which the Concept Needs to be Integrated Into Today's Design Process, Leeds Beckett University 